\title{
Haemoglobin concentration and mass as determinants of exercise performance and of surgical outcome
}

\author{
James M Otto ${ }^{*}$, Hugh E Montgomery ${ }^{2}$ and Toby Richards ${ }^{1}$
}

\begin{abstract}
The ability of the cardiorespiratory system (heart, lungs, blood) to deliver oxygen to exercising skeletal muscle constrains maximum oxygen consumption $\left(\dot{\mathrm{V}}_{2 \mathrm{max}}\right)$, with cardiac output and the concentration of oxygen-carrying haemoglobin ([Hb]) being key limiting parameters. Total blood volume (BV) is the sum of the plasma volume (PV) and the total red cell volume. The measured $[\mathrm{Hb}]$ is dependent upon the total circulating mass of haemoglobin (tHb-mass) and plasma volume (PV). While the proportion of oxygen carried in plasma is trivial $(0.3 \mathrm{~mL}$ of oxygen per $100 \mathrm{~mL}$ of plasma), each gram of $\mathrm{Hb}$, contained in red blood cells, binds $1.39 \mathrm{~mL}$ of oxygen. As a result, the relationship between $\dot{\mathrm{V}} \mathrm{O}_{2 \max }$ and thb-mass is stronger than that observed between $\dot{\mathrm{V}} \mathrm{O}_{2 \max }$ and [Hb] or BV. The glycoprotein hormone erythropoietin drives red cell synthesis and, like simple transfusion of packed red blood cells, can increase tHb-mass. An iron-containing haem group lies at the centre of the $\mathrm{Hb}$ molecule and, in situations of actual or functional iron deficiency, tHb-mass will also rise following iron administration. However achieved, an increase in tHb-mass also increases circulating oxygen-carrying capacity, and thus the capacity for aerobic phosphorylation. It is for such reasons that alterations in $\dot{\mathrm{VO}_{2 m a x}}$ and exercise performance are proportional to those in arterial oxygen content and systemic oxygen transport, a change in tHb-mass of $1 \mathrm{~g}$ being associated with a $4 \mathrm{~mL} \cdot \mathrm{min}^{-1}$ change in $\dot{\mathrm{V}} \mathrm{O}_{2 \max }$. Similarly, $\dot{\mathrm{V}} \mathrm{O}_{2 \max }$ increases by approximately $1 \%$ for each $3 \mathrm{~g} \cdot \mathrm{L}^{-1}$ increase in $[\mathrm{Hb}]$ over the $[\mathrm{Hb}$ ] range $\left(120\right.$ to $\left.170 \mathrm{~g} \cdot \mathrm{L}^{-1}\right)$. Surgery, like exercise, places substantial metabolic demands on the patient. Whilst subject to debate, oxygen supply at a rate inadequate to prevent muscle anaerobiosis may underpin the occurrence of the anaerobic threshold (AT), an important submaximal marker of cardiorespiratory fitness. Preoperatively, cardiopulmonary exercise testing (CPET) can be used to determine AT and peak exertional oxygen uptake $\left(\mathrm{V}_{2}\right.$ peak) as measures of ability to meet increasing oxygen demands. The degree of surgical insult and the ability to meet the resulting additional postoperative oxygen demand appear to be fundamental determinants of surgical outcome: individuals in whom such ability is impaired (and thus those with reduced $\dot{\mathrm{V}}_{2}$ peak and AT) are at greater risk of adverse surgical outcome. This review provides an overview of the relationships between $[\mathrm{Hb}]$, tHb-mass, exercise capacity, and surgical outcome and discusses the potential value of assessing tHb-mass over [Hb].
\end{abstract}

Keywords: Total haemoglobin mass, tHb-mass, Haemoglobin concentration, Cardiorespiratory fitness, CPET, Surgical outcome

\footnotetext{
* Correspondence: james.otto@ucl.ac.uk

${ }^{1}$ Division of Surgery and Interventional Science, c/o 4th Floor, Rockefeller Building, 21 University Street, London WC1E 6DE, UK

Full list of author information is available at the end of the article
} 


\section{Review}

Introduction

Oxygen $\left(\mathrm{O}_{2}\right)$ must be transported effectively from the atmosphere to the tissues in order to maintain essential metabolic pathways [1]. The heart, vasculature, and blood function to deliver a sufficient supply of $\mathrm{O}_{2}$, as well as metabolic substrate, to the tissues to allow effective resynthesis of adenosine triphosphate (ATP) via the electron transport chain (ETC.) [2]. Importantly, $\mathrm{O}_{2}$ is the final step in this process acting as the final electron acceptor in the ETC. [3]. Without adequate $\mathrm{O}_{2}$ transfer from the blood to the mitochondria, energy-generating mechanisms within the mitochondria would come to a halt [4]. At sites with insufficient $\mathrm{O}_{2}$ flow, anaerobic glycolytic metabolism complements ongoing aerobic ATP production, leading to a greater amount of lactic acid [4].

It is generally accepted that the physiological limits of the Fick equation determine the maximal rate at which $\mathrm{O}_{2}$ can be transported from the environment to the mitochondria and utilised to support oxidative phosphorylation, termed the maximal oxygen uptake $\left(\dot{\mathrm{V}}_{2 \max }\right)$ [5]. This is highlighted in endurance-trained athletes, where $\mathrm{O}_{2}$ transport is the most important limiting factor of $\dot{\mathrm{V}}_{2 \max }$, while mitochondrial $\mathrm{O}_{2}$ consumption also limits $\dot{\mathrm{V}} \mathrm{O}_{2 \max }$ in untrained individuals [6]. $\dot{\mathrm{V}} \mathrm{O}_{2 \max }$ is attained by the simultaneous increase in $\dot{Q}(\mathrm{SV} \times \mathrm{HR})$ and $\mathrm{CaO}_{2}-\mathrm{CvO}_{2}$, where $\dot{Q}$ is the cardiac output (determined by the stroke volume (SV) and the heart rate (HR)) and $\mathrm{CaO}_{2}-\mathrm{CvO}_{2}$ is the arteriovenous oxygen content difference. The ability to increase $\mathrm{CaO}_{2}-\mathrm{CvO}_{2}$ depends primarily on the arterial $\mathrm{O}_{2}$ content and haemoglobin concentration [Hb] [4].

Haemoglobin is an iron-containing globular protein pigment molecule carried within red blood cells (RBCs) [7]. Haemoglobin carries almost all of the $\mathrm{O}_{2}$ in the blood, with a trivial amount dissolved in plasma $(0.3 \mathrm{~mL}$ $\mathrm{O}_{2}$ per $100 \mathrm{~mL}$ of plasma) [8]. When fully saturated, assuming a normal $[\mathrm{Hb}]$ (e.g. $14 \mathrm{~g} \cdot \mathrm{dL}^{-1}$ in men) and a constant oxygen capacity of haemoglobin $\left(1.39 \mathrm{~mL} \cdot \mathrm{g}^{-1}\right)$, haemoglobin carries nearly $20 \mathrm{~mL}$ of $\mathrm{O}_{2}$ per $100 \mathrm{~mL}$ of whole blood [7].

Total haemoglobin mass (tHb-mass) represents the absolute mass of circulating haemoglobin in the body, and can now be quickly, safely, cheaply, and reliably measured using the optimised carbon monoxide $(\mathrm{CO})$ re-breathing method refined by Schmidt and Prommer [9]. Total blood volume (BV) is the sum of plasma volume (PV) and total red cell volume. The measured $[\mathrm{Hb}]$ is dependent upon the total circulating mass of haemoglobin (tHb-mass) and plasma volume (PV). However, the proportion of oxygen carried in plasma is trivial, whilst each gram of $\mathrm{Hb}$ binds $1.39 \mathrm{~mL}$ of oxygen. Thus, tHb-mass largely determines blood $\mathrm{O}_{2}$-carrying capacity.
In addition, however, tHb-mass can increase $\mathrm{BV}$ via its impact on erythrocyte volume [10]. A high BV is essential for achieving a high $\dot{Q}$ as observed in endurance athletes $[11,12]$. Thus, tHb-mass may be a more sensitive marker of blood $\mathrm{O}_{2}$ carrying capacity than using $[\mathrm{Hb}]$, and has additional influences (e.g. via impacts on BV) on physical performance than $[\mathrm{Hb}]$.

This review provides an overview of the relationships between $[\mathrm{Hb}], \mathrm{tHb}$-mass, exercise capacity, and surgical outcome, and discusses the potential value of assessing tHb-mass over $[\mathrm{Hb}]$.

\section{Manipulation of haemoglobin concentration and physical performance}

The link between the $\mathrm{O}_{2}$-carrying capacity of the blood and indices of exercise capacity such as $\mathrm{V}_{2 \max }$ has a long history. This section will focus on the effects of elevating and reducing $[\mathrm{Hb}]$ on markers of cardiorespiratory fitness.

\section{Elevation of haemoglobin concentration and maximal oxygen consumption}

$\dot{\mathrm{V}} \mathrm{O}_{2 \max }$ rises when systemic $[\mathrm{Hb}]$ is increased by $\mathrm{RBC}$ infusion [13-21] (Figure 1). $\dot{\mathrm{V}} \mathrm{O}_{2 \max }$ and/or exercise endurance have also been shown to increase in circumstances where

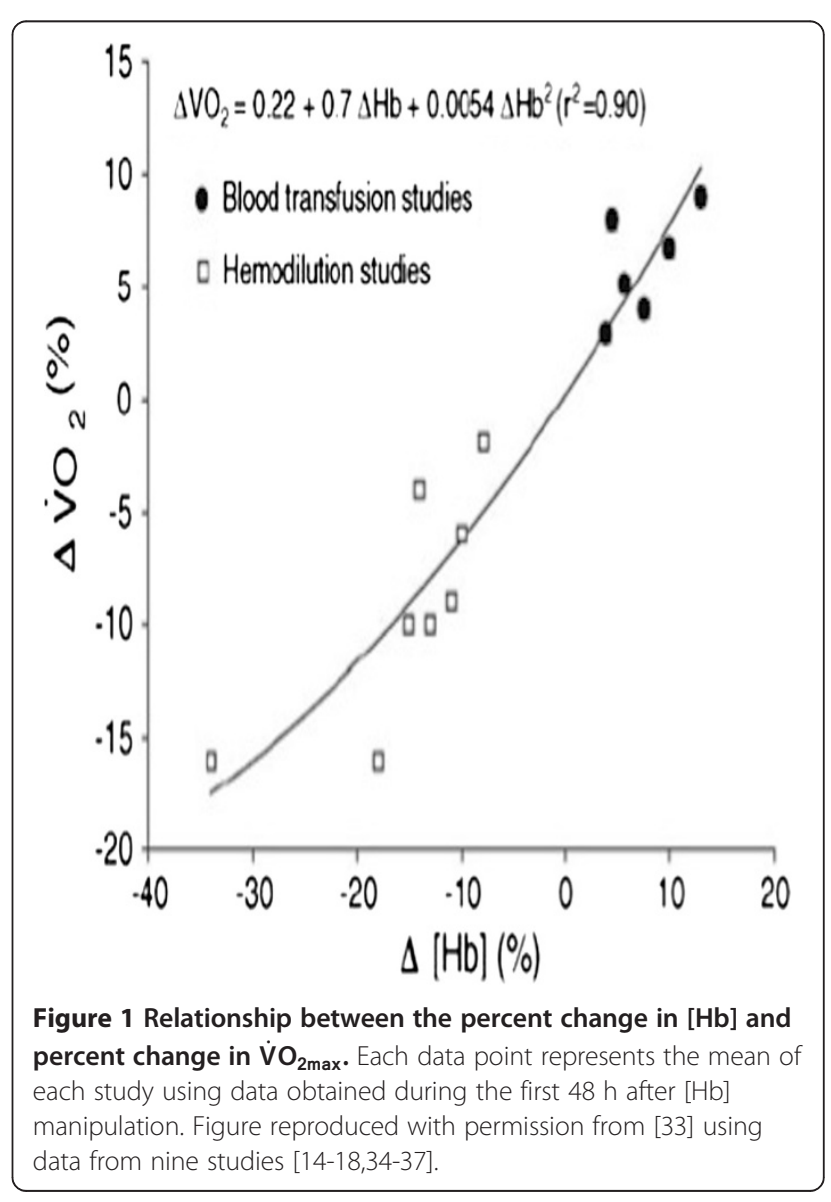


[Hb] has been elevated by the administration of recombinant human erythropoietin (rhEPO) to healthy individuals $[22,23]$, athletes $[23,24]$, haemodialysis patients $[25,26]$, and patients with heart failure $[27,28]$, or through the increased $\mathrm{Hb}$ synthesis following administration of iron supplements [29]. Studies that have failed to find such a relationship between $[\mathrm{Hb}$ ] and exercise capacity [30] may in part be explained by (i) a small quantity of blood being reinfused, (ii) insufficient time for the body to adapt its normal $[\mathrm{Hb}]$ post venesection, and (iii) inadequate storage of the RBCs [31]. When these factors are appropriately controlled for, elevating $[\mathrm{Hb}]$ is shown to increase $\dot{\mathrm{V}} \mathrm{O}_{2 \max }$ and endurance performance [13]. Gledhill and colleagues [31,32] have postulated that $\dot{\mathrm{V}} \mathrm{O}_{2 \max }$ increases by approximately $1 \%$ for each $3 \mathrm{~g} \cdot \mathrm{L}^{-1}[\mathrm{Hb}]$ over the $[\mathrm{Hb}]$ range $\left(120\right.$ to $\left.170 \mathrm{~g} \cdot \mathrm{L}^{-1}\right)$.

\section{Reduction of haemoglobin concentration and maximal oxygen consumption}

Early work by Ekblom and colleagues [14] demonstrated, in four participants, that a $13 \%$ reduction in $[\mathrm{Hb}]$ (by venesection of $800 \mathrm{~mL}$ of blood) lowered $\dot{\mathrm{V}} \mathrm{V}_{2 \max }$ by $10 \%$ (from 4.54 to $4.09 \mathrm{~L} \cdot \mathrm{min}^{-1}$ ) with a greater effect on endurance time observed (reduced by $30 \%$ from 5.77 to $4.04 \mathrm{~min}$ ). In the same study, an additional four participants underwent sequential venesection of 400, 800, and $1,200 \mathrm{~mL}$ of whole blood (at 4-day intervals) that resulted in a reduction in $[\mathrm{Hb}]$ of $10 \%, 15 \%$, and $18 \%$, respectively. These reductions were mirrored by a stepwise impairment in $\dot{\mathrm{V}} \mathrm{O}_{2 \max }(6 \%, 10 \%$, and $16 \%$ reduction) and endurance times (13\%, 21\%, and 30\% reduction).

Similar findings have been shown by a number of different authors including Balke et al. (9\% decrease in $\dot{\mathrm{V}}{ }_{2 \max } 1 \mathrm{~h}$ after a $500-\mathrm{mL}$ venesection) [34], Woodson and colleagues (16\% decline in $\dot{\mathrm{V}} \mathrm{O}_{2 \max }$ after $34 \%$ reduction of [Hb]) [35], Kanstrup and Ekblom (9\% reduction in $\dot{\mathrm{VO}}_{2 \max }$ and $40 \%$ lower endurance time at the intensity eliciting $\dot{\mathrm{V}} \mathrm{O}_{2 \max }$ after reducing $[\mathrm{Hb}]$ by $11 \%$ through the removal of $900 \mathrm{~mL}$ blood) [36] and to a lesser extent by Rowell et al. (4\% decrease in $\dot{\mathrm{V}} \mathrm{O}_{2 \max }$ following a $14 \%$ decrease in circulating $[\mathrm{Hb}]$ after repeated phlebotomies totaling 700-1,000 $\mathrm{mL}$ over 5 days) [37].

\section{Change in haemoglobin concentration and anaerobic threshold}

Compared to $\dot{\mathrm{V}} \mathrm{O}_{2}$ peak or $\dot{\mathrm{V}} \mathrm{O}_{2 \text { max }}$, less is known about the impact of changes in $[\mathrm{Hb}]$ on submaximal markers of cardiorespiratory fitness such as the AT. The AT represents the highest $\dot{\mathrm{VO}}_{2}$ (or running speed, power output) that can be performed without developing a sustained lactic acidosis [38].

Fritsch and colleagues [39] reported CPET in 16 young healthy participants before and 2 days after a $450-\mathrm{mL}$ venesection that resulted in $[\mathrm{Hb}]$ being reduced from 14.5 to $13.0 \mathrm{~g} \cdot \mathrm{dL}^{-1}$ (not classified as anaemic if using the World Health Organisation recommendations [40]). The AT was reduced following venesection when expressed as a percentage of $\dot{\mathrm{V}} \mathrm{O}_{2 \max }$ (pre $68.5 \%$ versus post $52 \%$ ) and as an absolute $\dot{\mathrm{V}} \mathrm{O}_{2}$. Our laboratory [41] has shown an independent association between preoperative $[\mathrm{Hb}]$ and $\mathrm{AT}$ after adjusting $\dot{\mathrm{VO}}_{2}$ values for known confounders (age, sex, testing site, operation category, diabetes, creatinine) and performing allometric scaling to remove the influence of body size from $\dot{\mathrm{VO}}_{2}$ values. Causality cannot be conferred from these data, but nonetheless demonstrate that those patients with the lowest $[\mathrm{Hb}]$ displayed the lowest $\dot{\mathrm{VO}}_{2}$ values and vice versa. Data from Japan [42] suggest that the AT is lower in patients with iron deficiency anaemia than in non-athletic controls (AT $15.9 \pm 3.3$ versus $21.3 \pm 1.3 \mathrm{~mL} \cdot \mathrm{kg}^{-1} \cdot \mathrm{min}^{-1}$, $p<0.01)$ and responds to increases in $[\mathrm{Hb}]$ following iron supplementation ([Hb] $9.0 \pm 1.8$ to $\left.12.1 \pm 0.8 \mathrm{~g} \cdot \mathrm{dL}^{-1}\right)$, AT $\left(20.9 \pm 6.3\right.$ to $\left.25.0 \pm 8.0 \mathrm{~mL} \cdot \mathrm{kg}^{-1} \cdot \mathrm{min}^{-1}, p<0.001\right)$.

\section{Relationship between tHb-mass, blood volume, and exercise capacity}

The relationship between markers of cardiorespiratory fitness and tHb-mass is stronger than that with $\mathrm{BV}$ or [Hb] $[43,44]$. A high correlation between tHb-mass and $\dot{\mathrm{V}} \mathrm{O}_{2 \max }(r=0.97)$ was observed in the early 1950 s by Astrand [45], where differences in maximal aerobic capacity between adults and children and between men and women were related to differences in total haemoglobin (see Figure 2). This initial investigation laid the foundation for much of the subsequent work in relation to tHb-mass and aerobic capacity.

Subsequently, undertaking a meta-analytical approach, Schmidt and Prommer [43] pooled data from 611 subjects. $\dot{\mathrm{V}} \mathrm{O}_{2 \max }$ was determined using either an incremental cycle ergometry test or treadmill protocol, with. values obtained from treadmill exercise adjusted (specifically reduced) by $7 \%$ to account for the greater muscle mass utilised compared to cycling. tHb-mass was measured in all subjects using the $\mathrm{CO}$ re-breathing technique. Results revealed a high correlation $(r=0.79)$ between $\dot{\mathrm{VO}_{2 \max }}$ and $\mathrm{tHb}$-mass. A similar close dependency between $\mathrm{BV}$ and $\dot{\mathrm{V}} \mathrm{O}_{2 \max }(r=0.76)$ was highlighted, in keeping with early work by Convertino that showed a similar relationship between total $\mathrm{BV}$ and $\dot{\mathrm{V}} \mathrm{O}_{2 \max }(r=0.78)$ [47]. No significant dependency of $\dot{\mathrm{V}} \mathrm{O}_{2 \max }$ on [Hb] (males $r=0.03$, females $r=0.12$ ) or Hct (males $r=0.08$, females $r=0.11$ ) was observed.

A number of other cross-sectional studies have demonstrated a strong positive association between $\dot{\mathrm{V}} \mathrm{O}_{2 \max }$ and tHb-mass including that by Gore and colleagues [48] who studied a cohort of trained athletes, female rowers $(\mathrm{n}=17, \mathrm{r}=0.92, \mathrm{p}<0.0001)$, male rowers $(n=$ $12, r=0.79, p<0.005)$ and male runners $(n=33, r=0.48$, $p=0.005)$. Likewise, Heinicke et al. [49] investigated BV 
and tHb-mass in elite athletes of different disciplines (downhill skiing, swimming, running, triathlon, cycling junior, and cycling professional), finding that $\dot{\mathrm{V}}_{2 \max }$ was significantly related to tHb-mass not only in the whole group but also in all endurance disciplines.

\section{Changes in tHb-mass and exercise capacity}

Procedures to increase tHb-mass result in elevated $\dot{\mathrm{VO}}_{2 \max }$ , whereas the opposite is true when tHb-mass is reduced [36], highlighting the importance of tHb-mass as a primary determinant of $\dot{\mathrm{V}}_{2 \max }$ by determining $\mathrm{O}_{2}$-carrying capacity.

\section{Elevation of thb-mass and exercise capacity}

When tHb-mass is increased through the use of rhEPO, concomitant increases in $\dot{\mathrm{V}}_{2 \max }$ have been reported. Specifically, $\dot{\mathrm{V}} \mathrm{O}_{2 \max }$ increased by $6 \%-7 \%$ in 27 recreational athletes after an increase in tHb-mass of $7 \%-12 \%$ and both fitness and blood parameters returned to baseline after cessation of rhEPO [50]. Similarly, a recent study in 19 trained men showed an improved 3,000-m running time trial performance (11:08 $\pm 1: 15$ to $10: 30 \pm$ 1:07 $\mathrm{min} / \mathrm{sec}, p<0.001)$ following 4 weeks of rhEPO administration. This improved performance coincided with a rhEPO-induced increase in $\dot{\mathrm{V}}_{2 \max }(56.0 \pm 6.2$ to

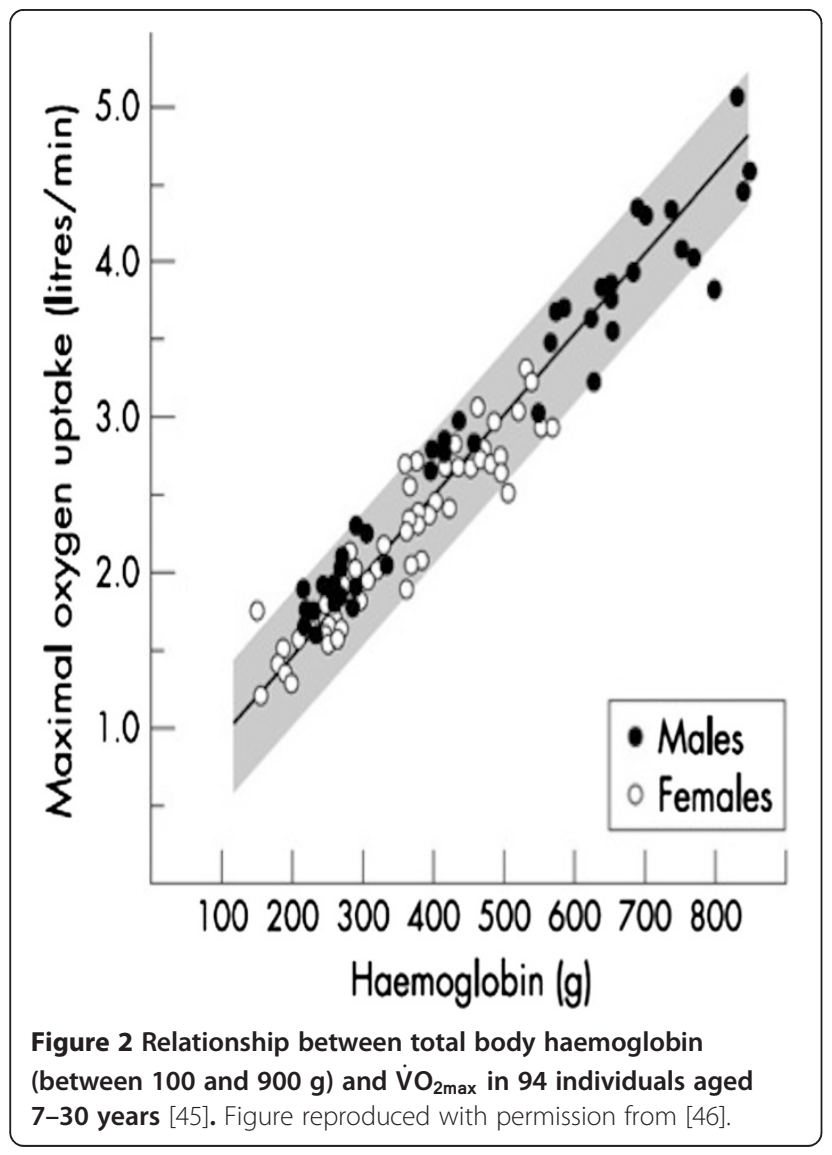

$\left.60.7 \pm 5.8 \mathrm{~mL} \cdot \mathrm{kg}^{-1} \cdot \mathrm{min}^{-1}, \quad p<0.001\right)$ and tHb-mass $\left(12.7 \pm 1.2\right.$ to $\left.15.2 \pm 1.5 \mathrm{~g} \cdot \mathrm{kg}^{-1}, p<0.001\right)$.

What change in aerobic capacity can we expect for a given change in tHb-mass? Linear regression analysis revealed a change in tHb-mass of $1 \mathrm{~g} \cdot \mathrm{kg}^{-1}$ was associated with a change in $\dot{\mathrm{V}} \mathrm{O}_{2 \max }$ of $4.4 \mathrm{~mL} \cdot \mathrm{kg}^{-1} \cdot \mathrm{min}^{-1}$ (males $4.2 \mathrm{~mL} \cdot \mathrm{kg}^{-1} \cdot \mathrm{min}^{-1}$, females $4.6 \mathrm{~mL} \cdot \mathrm{kg}^{-1} \cdot \mathrm{min}^{-1}$ ) and a change in $\mathrm{BV}$ of $1 \mathrm{~mL}$ blood per kilogram was related to a change in $\dot{\mathrm{V}} \mathrm{O}_{2 \max }$ of $0.7 \mathrm{~mL} \cdot \mathrm{kg}^{-1} \cdot \mathrm{min}^{-1}$ [43]. In 144 male athletes of various specialities with absolute $\dot{\mathrm{V}} \mathrm{O}_{2 \max }$ values ranging from 1,010 to $6,320 \mathrm{~mL} \cdot \mathrm{min}^{-1}$ and tHb-mass from 242 to $1,453 \mathrm{~g}$, a change in $1 \mathrm{~g}$ of haemoglobin was associated with a change in $\dot{\mathrm{V}}_{2 \max }$ by around $4 \mathrm{~mL} \cdot \mathrm{min}^{-1}$ [51]. This is the same as reported by Gore and colleagues [48] and very similar to that recently reported in an excellent review article in this area [10]. Understanding what change in aerobic capacity we can expect from a change in tHb-mass is important because it allows an accurate prediction of likely improvements in functional capacity as a result of an intervention to improve tHb-mass.

\section{Reduction of thb-mass and exercise capacity}

After $550 \mathrm{~mL}$ of whole blood had been withdrawn from 9 moderately trained male and female athletes, $\mathrm{tHb}$-mass was reduced on average by $77 \pm 21 \mathrm{~g}$ [52]. This was significantly associated with a decline in $\dot{\mathrm{V}} \mathrm{O}_{2 \max }$ of $255 \pm$ $130 \mathrm{~mL} \cdot \mathrm{min}^{-1}$ (1 day post phlebotomy) and was still decreased on day $10\left(197 \pm 116 \mathrm{~mL} \cdot \mathrm{min}^{-1}\right)$. The authors commented on a suppression of endurance performance during this period of lower tHb-mass. tHb-mass has also been shown to be reduced $(868 \pm 99$ to $840 \pm 94 \mathrm{~g}, p=0.03)$ following a 30-day detraining period (87\% reduction in training hours) with a reciprocal decrease in $\dot{\mathrm{V}} \mathrm{O}_{2 \max }(4.83 \pm 0.29$ to $4.61 \pm 0.41 \mathrm{~L}$. $\mathrm{min}^{-1}$ ) observed [53]. Given these findings and that tHb-mass is lower in healthy sedentary individuals than in those who are athletically trained [54], would sick patients have a lower tHb-mass by virtue of inactivity? And might the relationship between lower aerobic capacity and poorer operative outcome be in part mediated through a sedentary lifestyle-associated reduction in tHb-mass?

\section{Mechanisms for reduced exercise capacity following haematological changes}

A reduction in $[\mathrm{Hb}]$ due to a fall in tHb-mass may impair exercise capacity in a number of ways. Firstly, a reduction in $\mathrm{CaO}_{2}$ will reduce muscle $\mathrm{O}_{2}$ availability $\left(\mathrm{O}_{2}\right.$ delivery) for the same muscle blood flow [55]. Secondly, muscle $\mathrm{O}_{2}$-diffusing capacity is lower when $[\mathrm{Hb}]$ is reduced, which may be related to alterations in the intracapillary spacing of erythrocytes or slower dissociation of $\mathrm{O}_{2}$ from [Hb] [56]. Thirdly, pulmonary diffusion is 
reduced when $[\mathrm{Hb}]$ is reduced. Finally, a reduction in circulating BV may also impact aerobic capacity by affecting ventricular preload (diastolic function) via the FrankStarling mechanism, thus altering SV and $\dot{Q}[11,57]$. However, it appears that the predominant mechanism explaining the detrimental impact of reduced $[\mathrm{Hb}]$ on $\dot{\mathrm{V}} \mathrm{O}_{2 \max }$ and (to a greater extent) exercise endurance is the lowered $\mathrm{O}_{2}$-carrying capacity of the blood [33], with [Hb] being more important to $\dot{\mathrm{VO}}_{2 \max }$ in the untrained than in trained individuals [6]. This may have significant implications in patient populations.

Similar mechanisms may underpin the reduced AT observed when $[\mathrm{Hb}]$ is reduced but this is a much-debated and controversial concept $[58,59]$. The AT represents the highest $\dot{\mathrm{V}}_{2}$ (or running speed, power output) that can be performed without developing a sustained lactic acidosis [38]. When performing exercise above the AT, it is suggested that the metabolic demands of tissues (mitochondria) outstrips $\mathrm{O}_{2}$ supply, and aerobic ATP resynthesis is supplemented by anaerobic metabolism leading to increased lactate production relative to the rate of glycolysis (i.e. increased lactate/pyruvate ratio) [60]. The AT is therefore an important marker of cardiorespiratory fitness as it provides an assessment of the ability of the cardiovascular system to supply $\mathrm{O}_{2}$ at a rate adequate to prevent muscle anaerobiosis [38]. A reduced capacity to supply $\mathrm{O}_{2}$ to actively respiring tissues caused by low $[\mathrm{Hb}]$ or cardiovascular disease conditions has the potential to reduce the AT.

Surgical outcome, tHb-mass, and cardiorespiratory fitness The measurement of tHb-mass (rather than $[\mathrm{Hb}]$ ) in the clinical setting may have important applications but these remain relatively unexplored. For example, [Hb] may vary as intravascular fluid shifts as a result of disease states or their treatment, making it a poor index of oxygen-carrying capacity. $[\mathrm{Hb}]$ is determined by $\mathrm{tHb}$ mass and the total volume of blood. A substantial reduction in oxygen-carrying capacity, related to a low tHbmass, may thus be masked if PV is contracted, as may be the case in many disease states. Similarly, increases in intravascular volume may depress [Hb], even in the context of a normal tHb-mass. Knowledge of tHb-mass and $[\mathrm{Hb}]$ allows calculation of PV as a separate variable, allowing evaluation of disease-related fluid shifts. The degree of surgical blood loss might also be better quantified through the measurement of tHb-mass than $[\mathrm{Hb}]$. More importantly, perhaps, tHb-mass may represent a more sensitive marker of blood $\mathrm{O}_{2}$ transport capacity than $[\mathrm{Hb}]$ in isolation [61].

Major surgery can be defined as any intervention occurring in a hospital operating theatre involving the incision, excision, manipulation, or suturing of tissue, usually requiring regional or general anaesthesia or sedation [62]. The determinants of surgical outcome (morbidity and mortality) are related to an interplay between the health and fitness of patients, the number and severity of comorbidities present [63], and patient age as well as surgery-related factors (emergency or planned, mode, type, and duration). In addition, the systemic inflammatory response caused by hormonal, immunological, and metabolic mediators [64] is essential for effective tissue repair and healing after surgery. Effective $\mathrm{O}_{2}$ delivery to the tissues during the hypermetabolic postoperative period is thought to be a fundamental determinant of surgical outcome $[65,66]$ with patients who are unable to raise $\mathrm{O}_{2}$ delivery to meet the increased $\dot{\mathrm{V}} \mathrm{O}_{2}$ requirement more frequently developing complications $[67,68]$. The cause of this uncoupling of $\mathrm{O}_{2}$ supply and demand is multifactorial but may be predominantly linked to the interaction between a patient's existing comorbidities (e.g. cardiac disease, respiratory disease, or indeed any condition that impairs $\mathrm{O}_{2}$ delivery and/or cardiac output) and the degree of surgical insult [69].

Impairment in the ability to meet these demands can be determined preoperatively through the assessment of exertional $\mathrm{V}_{2}$ peak and AT (by CPET); reductions in both markers of functional capacity are associated with an increased risk of perioperative morbidity and mortality [70-74]. The original work by Older and colleagues almost 2 decades ago was the first to highlight the association between low functional capacity by CPET and adverse patient outcome following non-cardiopulmonary surgery [75]. Specifically, a reduced cardiorespiratory reserve, typically defined as an AT of less than $11 \mathrm{~mL}$. $\mathrm{kg}^{-1} \cdot \mathrm{min}^{-1}$ being associated with an increased risk of adverse postoperative outcome following major intracavity surgery [74]. Similarly, impaired $\dot{\mathrm{VO}}_{2}$ peak has been shown to predict worse postoperative outcome following major lung resection $\left(\mathrm{V}_{2}\right.$ peak $<20 \mathrm{~mL} \cdot \mathrm{kg}^{-1}$. $\min ^{-1}[76],<15 \mathrm{~mL} \cdot \mathrm{kg}^{-1} \cdot \mathrm{min}^{-1}$ [77]) and bariatric surgery $\left(\dot{\mathrm{VO}}_{2}\right.$ peak $\left.<16 \mathrm{~mL} \cdot \mathrm{kg}^{-1} \cdot \mathrm{min}^{-1}\right)$ [78]. The reader is referred to an excellent systematic review in this area covering the role of CPET as a preoperative risk stratification tool in non-cardiopulmonary surgery for more details [74].

It is acknowledged that although the $\dot{\mathrm{V}}_{2}$ response from an exercise test is not directly comparable to that in a postoperative patient, common with exercise, $\dot{\mathrm{V}}_{2}$ postoperatively in major surgery is high [79]. For example, preoperative resting $\dot{\mathrm{VO}}_{2}$ has been shown to increase from 110 to approximately $170 \mathrm{~mL} \cdot \mathrm{min}^{-1} \cdot \mathrm{m}^{-2}$ $[80,81]$ indicating a greater requirement for $\mathrm{O}_{2}$ following surgery. In this context, tHb-mass may be important to surgical outcome due to its role in determining $\mathrm{O}_{2}$ delivery. This may be related to the close linear relationship that exists between tHb-mass, $\mathrm{BV}, \dot{Q}$, and aerobic capacity [10]. For example, a high BV is a prerequisite for a 
high tHb-mass, which in turn impacts upon $\dot{Q}$ by elevating venous return and cardiac filling pressures $[82,83]$. Because tHb-mass in combination with BV also governs $[\mathrm{Hb}]$ and therefore oxygen-carrying capacity, the effects of tHb-mass on determining $\mathrm{O}_{2}$ delivery are twofold. Given the close relationship between tHb-mass and aerobic capacity and the association between markers of cardiorespiratory fitness $\left(\dot{\mathrm{V}}_{2}\right.$ peak and AT) and surgical outcome, it would seem intuitive that a high tHb-mass may confer a survival advantage in the perioperative setting. If this is the case, then strategies aimed at elevating tHb-mass may improve outcome (morbidity and mortality) following surgery, but this remains to be confirmed. Given that anaemia is associated with an increased risk of adverse surgical outcome, it would be surprising if this relationship were not maintained for $\mathrm{tHb}$-mass.

\section{Conclusion}

Changes in $[\mathrm{Hb}]$ and tHb-mass are associated with reciprocal alterations in exercise capacity proportional to the change in oxygen-carrying capacity of the blood. tHb-mass displays a stronger relationship with $\dot{\mathrm{V}}_{2 \max }$ than $[\mathrm{Hb}]$ or BV. In the context of surgery, patients with an inability to raise oxygen delivery to meet the increased $\dot{\mathrm{V}}_{2}$ requirement of the perioperative period will more frequently develop complications. Impairment in the ability to meet these demands can be determined preoperatively through the assessment of exertional $\dot{\mathrm{VO}}_{2}$ peak and AT (by CPET), reductions in both markers being associated with an increased risk adverse surgical outcome. Whether differences in tHb-mass are associated with postoperative outcome is not known but an interesting question given the high prevalence of preoperative anaemia itself being associated with an increased risk of poor outcome. In addition, the extent to which postoperative outcomes are dependent upon interactions between $[\mathrm{Hb}]$, tHb-mass, and $\dot{\mathrm{VO}}_{2}$ is unknown and whether strategies to increase tHb-mass result in improved surgical outcome remains to be clarified.

\section{Abbreviations}

AT: anaerobic threshold; $\mathrm{CaO}_{2}-\mathrm{CVO}_{2}$ : arteriovenous oxygen content difference; BV: blood volume; CO: carbon monoxide; CPET: cardiopulmonary exercise testing; rhEPO: recombinant human erythropoietin; ESA: erythropoietin-stimulating agent; $\mathrm{EV}$ : erythrocyte volume; $\mathrm{DO}_{2}$ : oxygen delivery; $\mathrm{Hct}$ : haematocrit; $\mathrm{Hb}$ : haemoglobin concentration; $\mathrm{O}_{2}$ : oxygen; PA: physical activity; PV: plasma volume; tHb-mass: total haemoglobin mass; $\dot{\mathrm{V}} \mathrm{O}_{2}$ : oxygen consumption; $\dot{\mathrm{V}}_{2 \text { max }}$ : maximal oxygen consumption; $\dot{\mathrm{V}}_{2}$ peak: peak oxygen consumption; $\mathrm{CaO}_{2}$ : arterial oxygen content; $\dot{Q}$ : cardiac output.

\section{Competing interests}

JMO is receiving an Impact PhD Studentship part-funded by VIFOR (INTERNATIONAL) Inc. with a total funding of $£ 32,534$ over 3 years. All remaining authors declare that they have no competing interests.

\section{Authors' contributions}

$J M O, H E M$, and TR were responsible for drafting and revising the article. All authors read and approved the final manuscript.

\section{Author details}

'Division of Surgery and Interventional Science, c/o 4th Floor, Rockefeller Building, 21 University Street, London WC1E 6DE, UK. ${ }^{2}$ UCL Institute for Sport, c/o 4th Floor, Rockefeller Building, 21 University Street, London WC1E $6 \mathrm{DE}, \mathrm{UK}$.

Received: 7 May 2013 Accepted: 28 October 2013

Published: 26 Nov 2013

\section{References}

1. Vincent $\mathrm{J}, \mathrm{De}$ Backer $\mathrm{D}$ : Oxygen transport-the oxygen delivery controversy. Intensive Care Med 2004, 30(11):1990-1996.

2. Nathan AT, Singer M: The oxygen trail: tissue oxygenation. Br Med Bull 1999, 55(1):96-108.

3. Williams C: Haemoglobin-is more better? Nephrol Dial Transplant 1995, 10(Suppl 2):48-55.

4. Wasserman K, Hansen JE, Sue DY, Stringer WW, Whipp BJ: Principles of Exercise Testing and Interpretation Including Pathophysiology and Clinical Applications. Philadelphia: Lippincott Williams \& Wilkins; 2005.

5. Levine BD: VO2max: what do we know, and what do we still need to know? J Physiol 2008, 586(1):25-34.

6. Wagner PD: New ideas on limitations to VO2max. Exerc Sport Sci Rev 2000, 28(1):10-14.

7. McArdle DW, Katch Fl, Katch VL: Gas exchange and transport. In Exercise Physiology: Energy, Nutrition and Human Performance. Philadelphia, Pennsylvania: Lippincott Williams \& Wilkins: Darcy P; 2001:270-284

8. Pittman RN: Regulation of Tissue Oxygenation. Morgan \& Claypool Life Sciences: San Rafael, CA; 2011.

9. Schmidt W, Prommer N: The optimised CO-rebreathing method: a new tool to determine total haemoglobin mass routinely. Eur J Appl Physiol 2005, 95(5-6):486-495.

10. Schmidt $\mathrm{W}$, Prommer $\mathrm{N}$ : Impact of alterations in total hemoglobin mass on $\mathrm{VO}_{2}$ max. Exerc Sport Sci Rev 2010, 38(2):68-75.

11. Krip B, Gledhill N, Jamnik V, Warburton D: Effect of alterations in blood volume on cardiac function during maximal exercise. Med Sci Sports Exerc 1997, 29(11):1469-1476.

12. Ekblom B, Hermansen L: Cardiac output in athletes. J Appl Physiol 1968, 25(5):619-625.

13. Sawka MN, Young AJ: Acute polycythemia and human performance during exercise and exposure to extreme environments. Exerc Sport Sci Rev 1989, 17:265-293.

14. Ekblom B, Goldbarg AN, Gullbrin B: Response to exercise after blood loss and reinfusion. J Appl Physiol 1972, 33(2):175-180.

15. Ekblom B, Wilson G, Astrand PO: Central circulation during exercise after venesection and reinfusion of red blood cells. J Appl Physiol 1976, 40(3):379-383.

16. Buick FJ, Gledhill N, Froese AB, Spriet L, Meyers EC: Effects of induced erythrocythemia on aerobic work capacity. J Appl Physiol 1980, 48(4):636-642.

17. Turner DL, Hoppeler H, Noti C, Gurtner HP, Gerber H, Schena F, Kayser B, Ferretti G: Limitations to VO2max in humans after blood retransfusion. Respir Physiol 1993, 92(3):329-341.

18. Spriet LL, Gledhill N, Froese AB, Wilkes DL: Effect of graded erythrocythemia on cardiovascular and metabolic responses to exercise. J Appl Physiol 1986, 61(5):1942-1948.

19. Williams MH, Wesseldine $S$, Somma T, Schuster R: The effect of induced erythrocythemia upon 5-mile treadmill run time. Med Sci Sports Exerc 1981, 13(3):169-175.

20. Brien AJ, Simon TL: The effects of red blood cell infusion on 10-km race time. JAMA 1987, 257(20):2761-2765.

21. Celsing F, Svedenhag J, Pihlstedt P, Ekblom B: Effects of anaemia and stepwise-induced polycythaemia on maximal aerobic power in individuals with high and low haemoglobin concentrations. Acta Physio/ Scand 1987, 129(1):47-54.

22. Ekblom B, Berglund B: Effect of erythropoietin administration on maximal aerobic power. Scand J Med Sci Sports 1991, 1:88-93. 
23. Thomsen JJ, Rentsch RL, Robach P, Calbet JA, Boushel R, Rasmussen P, Juel C, Lundby $C$ : Prolonged administration of recombinant human erythropoietin increases submaximal performance more than maximal aerobic capacity. Eur J Appl Physiol 2007, 101(4):481-486.

24. Ekblom BT: Blood boosting and sport. Baillieres Best Pract Res Clin Endocrinol Metab 2000, 14(1):89-98.

25. Barany P, Freyschuss U, Pettersson E, Bergstrom J: Treatment of anaemia in haemodialysis patients with erythropoietin: long-term effects on exercise capacity. Clin Sci (Lond) 1993, 84(4):441-447.

26. Robertson HT, Haley NR, Guthrie M, Cardenas D, Eschbach JW, Adamson JW: Recombinant erythropoietin improves exercise capacity in anemic hemodialysis patients. Am J Kidney Dis 1990, 15(4):325-332.

27. Kotecha D, Ngo K, Walters JA, Manzano L, Palazzuoli A, Flather MD: Erythropoietin as a treatment of anemia in heart failure: systematic review of randomized trials. Am Heart J 2011, 161(5):822-831.

28. Lawler PR, Filion KB, Eisenberg MJ: Correcting anemia in heart failure: the efficacy and safety of erythropoiesis-stimulating agents. J Card Fail 2010, 16(8):649-658.

29. Magazanik A, Weinstein Y, Abarbanel J, Lewinski U, Shapiro Y, Inbar O, Epstein S: Effect of an iron supplement on body iron status and aerobic capacity of young training women. Eur J Appl Physiol Occup Physiol 1991, 62(5):317-323.

30. Robinson BF, Epstein SE, Kahler RL, Braunwal E: Circulatory effects of acute expansion of blood volume - studies during maximal exercise and at rest. Circ Res 1966, 19(1):26-32.

31. Gledhill N: Blood doping and related issues: a brief review. Med Sci Sports Exerc 1982, 14(3):183-189.

32. Gledhill N, Warburton D, Jamnik V: Haemoglobin, blood volume, cardiac function, and aerobic power. Can J Appl Physiol 1999, 24(1):54-65.

33. Calbet JA, Lundby C, Koskolou M, Boushel R: Importance of hemoglobin concentration to exercise: acute manipulations. Respir Physiol Neurobiol 2006, 151(2-3):132-140.

34. Balke B, Grillo GP, Konecci EB, Luft UC: Work capacity after blood donation. J Appl Physiol 1954, 7(3):231-238.

35. Woodson RD, Wills RE, Lenfant C: Effect of acute and established anemia on $\mathrm{O} 2$ transport at rest, submaximal and maximal work. J Appl Physiol 1978, 44(1):36-43.

36. Kanstrup IL, Ekblom B: Blood volume and hemoglobin concentration as determinants of maximal aerobic power. Med Sci Sports Exerc 1984, 16(3):256-262

37. Rowell LB, Taylor HL, Yang W: Limitations to prediction of maximal oxygen intake. J Appl Physiol 1964, 19(5):919-927.

38. Wasserman K, Beaver WL, Whipp BJ: Gas exchange theory and the lactic acidosis (anaerobic) threshold. Circulation 1990, 81(1 Suppl):॥14-||30.

39. Fritsch J, Winter UJ, Reupke I, Gitt AK, Berge PG, Hilger HH: Effect of a single blood donation on ergo-spirometrically determined cardiopulmonary performance capacity of young healthy probands. Z Kardio/ 1993, 82(7):425-431.

40. WHO: Iron Deficiency Anaemia. Geneva: Assessment, Prevention and Control (A Guide for Programme Managers); 2001:1-114.

41. Otto JM, O'Doherty AF, Hennis PJ, Cooper JA, Grocott MP, Snowden C, Carlisle JB, Swart M, Richards T, Montgomery HE: Association between preoperative haemoglobin concentration and cardiopulmonary exercise variables: a multicentre study. Perioperative Med 2013, 2(18):13.

42. Yonezawa K: Effect of blood hemoglobin concentration on anaerobic threshold. Hokkaido lgaky Zasshi 1991, 66(4):458-467.

43. Schmidt W, Prommer N: Effects of various training modalities on blood volume. Scand J Med Sci Sports 2008, 18(Suppl 1):57-69.

44. Sawka MN, Convertino VA, Eichner ER, Schnieder SM, Young AJ: Blood volume: importance and adaptations to exercise training, environmental stresses, and trauma/sickness. Med Sci Sports Exerc 2000, 32(2):332-348.

45. Astrand PO: Experimental studies of physical working capacity in relation to sex and age. Copenhagen: Munksgaard; 1952.

46. Joyner MJ: VO2max, blood doping, and erythropoietin. Br J Sports Med 2003, 37(3):190-191.

47. Convertino VA: Blood volume: its adaptation to endurance training. Med Sci Sports Exerc 1991, 23(12):1338-1348.

48. Gore CJ, Hahn AG, Burge CM, Telford RD: VO2max and haemoglobin mass of trained athletes during high intensity training. Int J Sports Med 1997, 18(6):477-482.
49. Heinicke K, Wolfarth B, Winchenbach P, Biermann B, Schmid A, Huber G, Friedmann B, Schmidt W: Blood volume and hemoglobin mass in elite athletes of different disciplines. Int J Sports Med 2001, 22(7):504-512.

50. Parisotto R, Gore CJ, Emslie KR, Ashenden MJ, Brugnara C, Howe C, Martin DT, Trout GJ, Hahn AG: A novel method utilising markers of altered erythropoiesis for the detection of recombinant human erythropoietin abuse in athletes. Haematologica 2000, 85(6):564-572.

51. Schmidt W, Doerfler C, Wachsmuth N, Voelzke C, Treff G, Thoma S, Steinacker J, Niess A, Prommer N: Influence of body mass, body composition and performance state on total hemoglobin mass. Med Sci Sports Exerc 2009, 41(5 Supplement 1):461

52. Prommer N, Heckel A, Schmidt W: Timeframe to detect blood withdrawal associated with autologous blood doping. Med Sci Sports Exerc 2007, 39:S3.

53. Eastwood A, Bourdon PC, Snowden KR, Gore CJ: Detraining decreases $\mathrm{Hb}$ (mass) of triathletes. Int J Sports Med 2012, 33(4):253-257.

54. Koponen AS, Peltonen JE, Paivinen MK, Aho JM, Hagglund HJ, Uusitalo AL, Lindholm HJ, Tikkanen HO: Low total haemoglobin mass, blood volume and aerobic capacity in men with type 1 diabetes. Eur J Appl Physiol 2013, 113(5):1181-8.

55. Burnley M, Roberts $\mathrm{CL}$, Thatcher R, Doust JH, Jones AM: Influence of blood donation on $\mathrm{O} 2$ uptake on-kinetics, peak $\mathrm{O} 2$ uptake and time to exhaustion during severe-intensity cycle exercise in humans. Exp Physiol 2006, 91(3):499-509.

56. Schaffartzik W, Barton ED, Poole DC, Tsukimoto K, Hogan MC, Bebout DE, Wagner PD: Effect of reduced hemoglobin concentration on leg oxygen uptake during maximal exercise in humans. J App/ Physiol 1993, 75(2):491-498. Discussion 489-90.

57. Warburton DE, Gledhill N, Jamnik VK, Krip B, Card N: Induced hypervolemia, cardiac function, VO2max, and performance of elite cyclists. Med Sci Sports Exerc 1999, 31(6):800-808.

58. Hopker JG, Jobson SA, Pandit JJ: Controversies in the physiological basis of the 'anaerobic threshold' and their implications for clinical cardiopulmonary exercise testing. Anaesthesia 2011, 66(2):111-123.

59. Whipp BJ, Ward SA: The physiological basis of the 'anaerobic threshold' and implications for clinical cardiopulmonary exercise testing. Anaesthesia 2011, 66(11):1048-1049. author reply 1049-50.

60. Wasserman K: Determinants and detection of anaerobic threshold and consequences of exercise above it. Circulation 1987, 76(6 Pt 2):VI29-VI39.

61. Kjellberg SR, Rudhe U, Sjostrand T: Increase of the amount of hemoglobin and blood volume in connection with physical training. Acta Physio/ Scand 1949, 19(2-3):146-151.

62. Weiser TG, Regenbogen SE, Thompson KD, Haynes AB, Lipsitz SR, Berry WR, Gawande AA: An estimation of the global volume of surgery: a modelling strategy based on available data. Lancet 2008, 372(9633):139-144.

63. Moonesinghe SR, Mythen MG, Grocott MP: Patient-related risk factors for postoperative adverse events. Curr Opin Crit Care 2009, 15(4):320-327.

64. Toft $P$, Tonnesen $E$ : The systemic inflammatory response to anaesthesia and surgery. Current Anaesthesia Critical Care 2008, 19(5):349-353.

65. Bland RD, Shoemaker WC: Common physiologic patterns in general surgical patients: hemodynamic and oxygen transport changes during and after operation in patients with and without associated medical problems. Surg Clin North Am 1985, 65(4):793-809.

66. Shoemaker WC, Appel PL, Waxman K, Schwartz S, Chang P: Clinical trial of survivors' cardiorespiratory patterns as therapeutic goals in critically ill postoperative patients. Crit Care Med 1982, 10(6):398-403.

67. Peerless JR, Alexander JJ, Pinchak AC, Piotrowski JJ, Malangoni MA: Oxygen delivery is an important predictor of outcome in patients with ruptured abdominal aortic aneurysms. Ann Surg 1998, 227(5):726-732. Discussion 732-4.

68. Kusano C, Baba M, Takao S, Sane S, Shimada M, Shirao K, Natsugoe S, Fukumoto T, Aikou T: Oxygen delivery as a factor in the development of fatal postoperative complications after oesophagectomy. Br J Surg 1997 , 84(2):252-257

69. Fleisher LA, Beckman JA, Brown KA, Calkins H, Chaikof E, Fleischmann KE, Freeman WK, Froehlich JB, Kasper EK, Kersten JR, Riegel B, Robb JF, Smith SC Jr, Jacobs AK, Adams CD, Anderson JL, Antman EM, Buller CE, Creager MA, Ettinger SM, Faxon DP, Fuster V, Halperin JL, Hiratzka LF, Hunt SA, Lytle BW, Nishimura R, Ornato JP, Page RL, Tarkington LG, Yancy CW: ACC/AHA 2007 guidelines on perioperative cardiovascular evaluation and care for noncardiac surgery: a report of the American College of Cardiology/ American Heart Association Task Force on Practice Guidelines (writing 
Committee to Revise the 2002 Guidelines on Perioperative Cardiovascular Evaluation for Noncardiac Surgery): developed in collaboration with the American Society of Echocardiography, American Society of Nuclear Cardiology, Heart Rhythm Society, Society of Cardiovascular Anesthesiologists, Society for Cardiovascular Angiography and Interventions, Society for Vascular Medicine and Biology, and Society for Vascular Surgery. Circulation 2007, 116(17):e418-e499.

70. Carlisle J, Swart M: Mid-term survival after abdominal aortic aneurysm surgery predicted by cardiopulmonary exercise testing. Br J Surg 2007, 94(8):966-969.

71. Older P, Hall A, Hader R: Cardiopulmonary exercise testing as a screening test for perioperative management of major surgery in the elderly. Chest 1999, 116(2):355-362.

72. Snowden CP, Prentis JM, Anderson HL, Roberts DR, Randles D, Renton M, Manas DM: Submaximal cardiopulmonary exercise testing predicts complications and hospital length of stay in patients undergoing major elective surgery. Ann Surg 2010, 251(3):535-541.

73. Wilson RJ, Davies S, Yates D, Redman J, Stone M: Impaired functional capacity is associated with all-cause mortality after major elective intra-abdominal surgery. Br J Anaesth 2010, 105(3):297-303.

74. Hennis PJ, Meale PM, Grocott MP: Cardiopulmonary exercise testing for the evaluation of perioperative risk in non-cardiopulmonary surgery. Postgrad Med J 2011, 87(1030):550-557.

75. Older P, Smith R, Courtney P, Hone R: Preoperative evaluation of cardiac failure and ischemia in elderly patients by cardiopulmonary exercise testing. Chest 1993, 104(3):701-704.

76. Brunelli A, Belardinelli R, Refai M, Salati M, Socci L, Pompili C, Sabbatini A: Peak oxygen consumption during cardiopulmonary exercise test improves risk stratification in candidates to major lung resection. Chest 2009, 135(5):1260-1267.

77. Bayram AS, Candan T, Gebitekin C: Preoperative maximal exercise oxygen consumption test predicts postoperative pulmonary morbidity following major lung resection. Respirology 2007, 12(4):505-510.

78. McCullough PA, Gallagher MJ, Dejong AT, Sandberg KR, Trivax JE, Alexander D, Kasturi G, Jafri SM, Krause KR, Chengelis DL, Moy J, Franklin BA: Cardiorespiratory fitness and short-term complications after bariatric surgery. Chest 2006, 130(2):517-525.

79. Older P: Anaerobic threshold, is it a magic number to determine fitness for surgery? Perioperative Med 2013, 2:2

80. Older P, Smith R: Experience with the preoperative invasive measurement of haemodynamic, respiratory and renal function in 100 elderly patients scheduled for major abdominal surgery. Anaesth Intensive Care 1988, 16(4):389-395.

81. Shoemaker WC, Appel PL, Kram HB, Waxman K, Lee TS: Prospective trial of supranormal values of survivors as therapeutic goals in high-risk surgical patients. Chest 1988, 94(6):1176-1186.

82. Young DB: Control of Cardiac Output. Morgan \& Claypool Life Sciences: San Rafael (VA); 2010.

83. Ekblom B: Effect of physical training on oxygen transport system in man. Acta Physiol Scand Suppl 1968, 328:1-45.

\subsection{6/2046-7648-2-33}

Cite this article as: Otto et al:: Haemoglobin concentration and mass as determinants of exercise performance and of surgical outcome. Extreme Physiology \& Medicine 2013, 2:33

\section{Submit your next manuscript to BioMed Central and take full advantage of:}

- Convenient online submission

- Thorough peer review

- No space constraints or color figure charges

- Immediate publication on acceptance

- Inclusion in PubMed, CAS, Scopus and Google Scholar

- Research which is freely available for redistribution 